\title{
SELECTED EXCIPIENTS IN ORAL SOLID DOSAGE FORM WITH DRY EXTRACT OF PYROLA ROTUNDIFOLIA L.
}

\section{NATALIA DARZULI, LILIIA BUDNIAK, TARAS HROSHOVYI}

\author{
Department of Pharmacy Management, Economics and Technology, I. Horbachevsky Ternopil National Medical University, Maidan Voli 1, \\ 46001, Ternopil, Ukraine \\ Email: stoyko_li@tdmu.edu.ua \\ Received: 09 Aug 2019, Revised and Accepted: 08 Oct 2019
}

\begin{abstract}
Objective: The aim of the present study was to select excipients in an oral solid dosage form with a dry extract of round-leaved wintergreen (Pyrola rotundifolia L.) by using asymmetric, rotatable composite plan of the second-order (uniform plan No. 17).

Methods: The tablets were prepared by using a direct compression method. The most important pharmaceutical factors selected were considered in more details at developing the optimal composition and technology of the studied tablets of the round-leaved wintergreen extract. Each one was studied at five levels using asymmetric, rotatable composite plan of the second order.

Results: Increasing amounts of PROSOLV® EASYtab SP and croscarmellose sodium in the powder mass, its flowability decreases, and increasing amounts of Tablettose ${ }^{\circledR} 80$ improves flowability. Increasing the amount of Tablettose ${ }^{\circledR} 80$ in the tablets composition leads to improved uniformity. The strength of the tablets increased with increasing amounts of Neusilin ${ }^{\circledR}$ US 2 at different combinations of levels of the other three factors. When studying the effect of the amounts of croscarmellose sodium on the disintegration of tablets, it was found that the best disintegration values were obtained in the study of croscarmellose sodium at the upper level.
\end{abstract}

Conclusion: Oral solid dosage form with dry extract of round-leaved wintergreen was successfully prepared by the direct compression method. The optimal composition of tablets was determined by the regression analysis.

Keywords: Pyrola rotundifolia L., Round-leaved wintergreen, Dry extract, Tablets, Mathematical planning of the experiment

(C) 2019 The Authors. Published by Innovare Academic Sciences Pvt Ltd. This is an open-access article under the CC BY license (http://creativecommons.org/licenses/by/4.0/) DOI: http://dx.doi.org/10.22159/ijap.2019v11i6.35282

\section{INTRODUCTION}

Kidney diseases are a very important medical and social problem, associated with widespread prevalence and significant risks of renal failure, disability and death as their consequences.

About $10 \%$ of the world population suffers from chronic kidney diseases [1]. The chronic kidney failure is one of the biggest challenges of modern nephrology since it is caused by the progressive course of chronic kidney disease [2].

Because of the development of chronic kidney failure, the number of patients who need the substitutive renal therapy (hemodialysis, peritoneal dialysis, kidney transplantation) increases annually. Such methods are extremely expensive and their usage is a huge economic problem all around the world.

Therefore, it is very important to prevent, diagnose and adequately treat all kidney diseases [1].

Nowadays, searching for plants with a long history of usage, minor side effects and high tolerability, regardless of the age of patients, as well as the development of effective medications on their basis for prevention and treatment of urinary system disorders are the objects of interest in our society [3].

Pyrola rotundifolia L. has a wide range of pharmacological activities: antimicrobial, diuretic, anti-inflammatory, and nephroprotective ones. Pyrola rotundifolia L., commonly known as round-leaved wintergreen, belonging to family Ericaceae.

The technology of getting the dry extract of round-leaved wintergreen was developed. The complex of the pharmacological action of the dry extract has been confirmed, which allows using it for the treatment and prevention of the urinary system diseases.

In previous studies, the effect of 27 excipients on the technological characteristics of round-leaved wintergreen extract tablets was studied.
Four of the best excipients have been identified, Neusilin ${ }^{\circledR}$ US 2, PROSOLV ${ }^{\circledR}$ EASYtab SP, sodium croscarmellose, Tablettose ${ }^{\circledR} 80$, which were selected for further investigation and determination of optimal composition using asymmetric, rotatable composite plan of the second order.

The purpose of the study was to select excipients in oral solid dosage form with dry extract of round-leaved wintergreen (Pyrola rotundifolia L.) by using a symmetric, rotatable composite plan of the second-order (uniform plan No. 17).

When planning an experiment, mathematical methods were used not only at the stage of processing the results but also at the very first stage of experimentation, called the creation of an experiment plan $[4,5]$.

\section{MATERIALS AND METHODS}

\section{Plant materials}

Round-leaved wintergreen was collected in Northern Ukraine, Kovel district, Volyn region (N $51^{\circ} 46^{\prime} 80.47^{\prime \prime}$ E $25^{\circ} 01^{\prime} 37.12 "$ ), during a mass flowering period in 2016. The raw material was authenticated by a senior researcher, Dr. Andriy Kotov (Ukrainian Scientific Pharmacopoeial Center for Quality of Medicines, Kharkiv, Ukraine). A voucher specimen no. 0118 is kept at the Department of Standardization of Herbal Drugs and Herbal Drug Preparation, Ukrainian Scientific Pharmacopoeial Center for Quality of Medicines, Kharkiv, Ukraine.

We have studied the following excipients in the development of the optimal composition of tablets: dry extract of round-leaved wintergreen, Neusilin ${ }^{\circledR}$ US 2(Fuji Chemical Industry Co., LTD, Japan), PROSOLV ${ }^{\circledR}$ EASYtab SP (JRS Parma LTD, Germany), croscarmellose sodium SOLUTAB ${ }^{\circledR}$ A (Roquette, France), Tablettose ${ }^{\circledR 80}$ (Meggle LTD, Germany), VIVAPUR ${ }^{\circledR} 112$ (JRS Parma LTD, Germany), magnesium stearate (Tablube ${ }^{\circledR} \mathrm{MgSt}$ micronized vegetable).

Four excipients were studied using asymmetric, rotatable composite plan of the second-order (uniform plan No. 17). The length of the star arm for this plan is 2.0. The star point was found by multiplying the variation interval by the star arm value. These values were 
added to the baseline, getting the upper star point $(«+\alpha »)$ and subtracted to obtain a lower star point $(\ll-\alpha »)[4]$.
When developing the optimal composition of the round-leaved wintergreen extract tablets, each of the four excipients was studied at five levels (table 1) [6, 7].

Table 1: Factors studied in the development of the optimal composition of the round-leaved wintergreen extract tablets

\begin{tabular}{|c|c|c|c|c|c|}
\hline \multirow[t]{2}{*}{ Factor } & \multicolumn{5}{|l|}{ Level of factor } \\
\hline & Lower star point «- $\alpha »$ & Lower «-» & Basic «0» & Upper «+» & Upper star point $«+\alpha »$ \\
\hline $\mathrm{x}_{1}$-quantity of Neusilin ${ }^{\circledR}$ US2, \% & 2 & 3 & 4 & 5 & 6 \\
\hline $\mathrm{x}_{2}$-quantity of PROSOLV ${ }^{\circledR}$ EASYtab SP, \% & 6 & 9 & 12 & 15 & 18 \\
\hline $\mathrm{x}_{3}$-quantity of croscarmellose sodium, $\%$ & 1 & 3 & 5 & 7 & 9 \\
\hline $\mathrm{x}_{4}$-quantity of Tablettose $\mathrm{e}^{\circledR} 80, \%$ & 1 & 4 & 7 & 10 & 13 \\
\hline
\end{tabular}

Neusilin ${ }^{\circledR}$ US 2 is a synthetic amorphous form of magnesium aluminometa silicate and is widely accepted as a multifunctional excipient that improves the quality of pharmaceuticals [8-10].

PROSOLV ${ }^{\circledR}$ EASYtab is a multi-functional co-processed excipient that produces similar functionalities to the physical mixture from its individual components while improving process-related quality attributes and minimizing undesirable properties that may be associated with the physical mixture [11].

PROSOLV ${ }^{\circledR}$ EASYtab SP is a complex excipients that combines MCC, silicon colloidal dioxide, sodium starch glycolate, sodium stearine fumarate [12].

Sodium croscarmellose was studied as a disintegrant to reduce the disintegration time of tablets [13].

Tablettose $^{\circledR} 80$ was specially developed for direct compression, combining good flowability and compressibility of various lactose fractions [14].

Magnesium stearate was studied as a lubricant, $1 \%$ of a tablet weight was added to each batch $[15,16]$.

VIVAPUR ${ }^{\circledR} 112$ is excipients, which brought tablets to a specific average weight of $0.6 \mathrm{~g}$ [17].

\section{Pre-compression evaluation}

In order to develop the optimal composition of the round-leaved wintergreen extract tablets by the direct compression method, the following technological operations were performed: sieving, weighing, mixing, powdering, and pressing. Model mixtures were prepared as follows: all the necessary components were weighed, sieved, a weighed active ingredient was added to VIVAPUR ${ }^{\circledR} 112$ dry extract of round-leaved wintergreen, stirred, PROSOLV ${ }^{\circledR}$ EASYtab SP, Tablettose ${ }^{\circledR} 80$ was added to the resulting mixture, stirred up, Neusilin ${ }^{\circledR}$ US 2 was added, mixed to uniformity, croscarmellose sodium was added and dusted with a lubricant. The powder mixture was mixed and its pharmacological properties were studied-flowability, bulk density and tapped density. After that, they pressed tablets on a tablet machine with a punch diameter of $12 \mathrm{~mm}$ and a mass of $0.6 \mathrm{~g}$ and studied the tableting process.

\section{Bulk density}

Bulk density was determined by pouring the powder into a graduated cylinder. The volume and weight of the mixture was determined. Bulk density is the ratio of the total weight of the powder to the bulk volume of the powder.

\section{Tapped density}

Tapped density is the ratio of the general mass of the powder to the tapped volume of the powder. The tapped density was measured by tapping the powder mixture for 500 times [18].

\section{Flowability}

The fluidity was determined using the stationary funnel method. The powder mixture $( \pm 100 \mathrm{~g})$ was poured through a funnel. The time of flow of the powder mixture through the funnel was used to calculate the flowability of the powder mixture [19].

\section{Tableting process}

When pressing tablets of tablets of dry extract of round-leaved wintergreen, the tableting process was evaluated on a scale from one to five. The pressing process was evaluated by the following criteria: matrix backfill, expelling effort, sticking of the tablet mass to the press. The following evaluation criteria were used.

5 points-the matrix is filled up homogeneously, the tablet mass and tablets do not stick to the press, the tablets are expelled without much effort.

4 points-the matrix is filled up almost homogeneously, punches have a slight residue, but the tablet mass and tablets do not stick to punches, tablets are expelled with the application of some effort.

3 points-the matrix is filled up heterogeneously, the tablet mass and tablets slightly stick to the punches, the tablets are expelled with much effort.

2 points-the matrix is not filled up with tablet mass, tablets stick to the press and are damage [20].

\section{Preparation and evaluation of tablets}

The powder mixture was stirred up prior to tabletting, part of the powder mixture was pressed on a laboratory tablet machine with a punch diameter of $12 \mathrm{~mm}$ and a weight of $0.6 \mathrm{~g}$, the obtained tablets were examined for appearance and uniformity of dosage units. The remaining powder mixture was pressed on a tablet press at a pressure of $50 \mathrm{~N}$ using a punch diameter of $12 \mathrm{~mm}$ and a tablet weight of $0.6 \mathrm{~g}$. The obtained tablets were tested for compliance with pharmacotechnological quality indicators, such as: disintegration, strength, abrasion.

\section{Tablets appearance}

Tablet's appearance was determined visually in daylight, viewing against a white background.

\section{Uniformity of weight}

Twenty tablets were weighed separately and the average weight was calculated, the deviation should not exceed $\pm 5 \%$ for tablets weighing $0.6 \mathrm{~g}$ [21].

\section{The tablets hardness}

The tablet's hardness was determined on a tablet analyzer ERWEKA TBH 220 D. Measurements were performed on 10 tablets. For tablets with a diameter of $12 \mathrm{~mm}$, the resistance to crushing must be at least $50 \mathrm{~N}$.

\section{The friability test}

Tests were performed to determine the tablets resistance to mechanical impact, or friability. In determining the friability, they used a drum unit with one blade. With a tablet weight of $0.6 \mathrm{~g}, 10$ tablets are weighed before and immediately after abrasion. Friability is expressed as a weight loss calculated as a percentage. The tablets withstood the test if they were not chipped or cracked and the friability value did not exceed $1 \%[19,21]$.

\section{The disintegration time}

Tablet disintegration tests were performed using an ERWEKA ZT 502 tablet and capsule disintegration device, maintaining the temperature $37 \pm 2{ }^{\circ} \mathrm{C}$. Disintegration of uncoated tablets should take no more than $15 \mathrm{~min}$. 


\section{Statistical analysis}

To process the experimental data obtained using the method of mathematical planning of the experiment used by Statistica 6.0. The level of significance was set at * $<0.05$ for all statistical analyses.

\section{RESULTS AND DISCUSSION}

The experiment planning matrix and the test results for tablets made of round-leaved wintergreen extract are shown in table 2.

The second order model for four factors is as follows $[22,23]$ :

$\mathrm{y}=\mathrm{b}_{0} \mathrm{x}_{0}+\mathrm{b}_{1} \mathrm{x}_{1}+\mathrm{b}_{2} \mathrm{x}_{2}+\mathrm{b}_{3} \mathrm{x}_{3}+\mathrm{b}_{4} \mathrm{x}_{4}+\mathrm{b}_{12} \mathrm{x}_{1} \mathrm{x}_{2}+\mathrm{b}_{13} \mathrm{x}_{1} \mathrm{x}_{3}+\mathrm{b}_{14} \mathrm{x}_{1} \mathrm{x}_{4}+\mathrm{b}_{23} \mathrm{x}_{2} \mathrm{x}_{3}+$ $\mathrm{b}_{24} \mathrm{X}_{2} \mathrm{X}_{4}++\mathrm{b}_{34} \mathrm{X}_{3} \mathrm{X}_{4}+\mathrm{b}_{11} \mathrm{x}_{1}^{2}+\mathrm{b}_{22} \mathrm{X}_{2}^{2}+\mathrm{b}_{33} \mathrm{X}_{3}^{2}+\mathrm{b}_{44} \mathrm{X}_{4}{ }^{2}$

The test results were interpreted based on the analysis of regression equations. The statistical significance of the coefficients and adequacy of the models were checked using the F-criterion [24]. The regression equations were adequate when $\mathrm{F}_{\text {test }}<\mathrm{F}_{\text {tabl }}$ [4]. Effect of the studied factors was determined by the values and operators of the regression coefficients.

Effect of the studied factors on the bulk density of powders containing round-leaved wintergreen extract is described by the following regression equation:

$\mathrm{y}_{1}=0,531-0,0088 \mathrm{x}_{1}+0,009 \mathrm{x}_{3}+0,01 \mathrm{x}_{4}+0,0032 \mathrm{x}_{1}{ }^{2}+0,003 \mathrm{x}_{2}{ }^{2}$

According to the regression equation, with increasing amounts of croscarmellose sodium and Tablettose ${ }^{\circledR 80}$, the bulk density of powders containing round-leaved wintergreen extract increases, and decreases with increasing Neusilin ${ }^{\circledR}$ US 2 .

The regression equation for the tapped density of powders containing round-leaved wintergreen extract has the following form:

$\mathrm{y}_{2}=0,6748-0,0089 \mathrm{x}_{1}+0,0091 \mathrm{x}_{3}+0,01 \mathrm{x}_{4}$

The studied factors affect the tapped density the same way as for the bulk density. The tapped density increases when the amount of croscarmellose sodium and Tablettose ${ }^{\circledR} 80$ increases, and decreases with increasing Neusilin ${ }^{\circledR}$ US 2 .

The relationship between the studied factors and flowability of the powders containing round-leaved wintergreen extract is described by the following regression equation:

$\mathrm{y}_{3}=31,35+1,3 \mathrm{x}_{1}+0,4 \mathrm{x}_{2}+0,23 \mathrm{x}_{3}-0,76 \mathrm{x}_{4}+0,14 \mathrm{x}_{1} \mathrm{x}_{4}+0,76 \mathrm{x}_{2} \mathrm{x}_{3}-0,27 \mathrm{x}_{2} \mathrm{x}_{4}-$ $0,34 \mathrm{x}_{3} \mathrm{x}_{4}+0,9 \mathrm{x}_{1}{ }^{2}+0,34 \mathrm{x}_{2}{ }^{2}-0,13 \mathrm{x}_{4}{ }^{2}$

When the coefficients of pair interactions are significant, it is advisable to interpret the regression equation using graphs.

For significant linear factors, the regression equations were interpreted using one-factor graphical drawings. In the regression equation, the factor $\mathrm{x}_{1}$ has the most significant effect. The effect of Neusilin ${ }^{\circledR}$ US 2 amount on flowability of powder mixtures containing round-leaved wintergreen extract is shown in fig. 1.

The fig. shows that when studying the amounts of PROSOLV ${ }^{\circledR}$ EASYtab SP $\left(\mathrm{x}_{2}\right)$, croscarmellose sodium $\left(\mathrm{x}_{3}\right)$ and Tablettose ${ }^{\circledR} 80\left(\mathrm{x}_{4}\right)$ at the basic level (line 1)-the flowability of the powder mixtures was the highest, the amounts of Neusilin ${ }^{\circledR}$ US $2\left(\mathrm{x}_{1}\right)$ at the bottom and basic levels had the most evident effect on flowability, with the Neusilin ${ }^{\circledR}$ US 2 on the upper and upper star points being studied, the response was significantly impaired. According to the regression equation, with increasing amounts of PROSOLV ${ }^{\circledR}$ EASYtab SP and croscarmellose sodium in the powder mass, its flowability decreases, and increasing amounts of Tablettose ${ }^{\circledR} 80$ improves flowability.

The effect of quantitative factors on the appearance of tablets of round-leaved wintergreen extract is described by the following regression equation:

$\mathrm{y}_{4}=4,93-0,08 \mathrm{x}_{2}-0,13 \mathrm{x}_{3}-0,13 \quad \mathrm{x}_{1} \mathrm{x}_{4}+0,19 \mathrm{x}_{2} \mathrm{x}_{3}-0,14 \mathrm{x}_{1}{ }^{2}-$ $0,20 \mathrm{x}_{2}{ }^{2}+0,08 \mathrm{x}_{3}{ }^{2}-0,08 \mathrm{x}_{4}{ }^{2}$

The effect of the most significant factor $x_{3}$ on the appearance of tablets of round-leaved wintergreen extract is shown in fig. 2

Table 2: The experiment planning matrix and the test results for tablets made of round-leaved wintergreen extract

\begin{tabular}{|c|c|c|c|c|c|c|c|c|c|c|c|c|c|}
\hline Butch number & $\mathrm{x}_{1}$ & $\mathbf{x}_{2}$ & $\mathbf{X}_{3}$ & $\mathbf{X}_{4}$ & $\mathbf{y}_{1}$ & $\mathbf{y}_{2}$ & $\mathbf{y}_{3}$ & $\mathbf{y}_{4}$ & $\mathbf{y}_{5}$ & $\mathbf{y}_{6}$ & $\mathbf{y}_{7}$ & $\mathbf{y}_{8}$ & $\mathrm{y}_{9}$ \\
\hline 1 & 2 & 3 & 4 & 5 & 6 & 7 & 8 & 10 & 11 & 12 & 13 & 14 & 15 \\
\hline 1 & 1 & 1 & 1 & 1 & 0,553 & 0,677 & 33,81 & 5 & 5,0 & 0,94 & 200 & 0,0662 & 9 \\
\hline 2 & -1 & 1 & 1 & 1 & 0,568 & 0,700 & 30,62 & 5 & 5,0 & 1,85 & 200 & 0,1327 & 10 \\
\hline 3 & 1 & -1 & 1 & 1 & 0,553 & 0,677 & 32,48 & 5 & 4,5 & 1,75 & 199 & 0,0331 & 9 \\
\hline 4 & -1 & -1 & 1 & 1 & 0,568 & 0,700 & 29,29 & 5 & 5,0 & 1,45 & 199 & 0,0993 & 9 \\
\hline 5 & 1 & 1 & -1 & 1 & 0,538 & 0,700 & 31,19 & 5 & 4,5 & 1,77 & 199 & 0,0663 & 12 \\
\hline 6 & -1 & 1 & -1 & 1 & 0,553 & 0,677 & 29,67 & 5 & 5,0 & 1,22 & 199 & 0,0995 & 12 \\
\hline 7 & 1 & -1 & -1 & 1 & 0,525 & 0,677 & 33,81 & 5 & 5,0 & 1,87 & 200 & 0,0663 & 14 \\
\hline 8 & -1 & -1 & -1 & 1 & 0,538 & 0,677 & 30,24 & 5 & 5,0 & 1,36 & 196 & 0,0663 & 11 \\
\hline 9 & 1 & 1 & 1 & -1 & 0,512 & 0,677 & 35,62 & 5 & 5,0 & 1,70 & 184 & 0,0994 & 9 \\
\hline 10 & -1 & 1 & 1 & -1 & 0,553 & 0,700 & 33,33 & 5 & 4,0 & 2,57 & 172 & 0,1321 & 8 \\
\hline 11 & 1 & -1 & 1 & -1 & 0,538 & 0,656 & 33,00 & 5 & 4,0 & 2,09 & 199 & 0,0331 & 10 \\
\hline 12 & -1 & -1 & 1 & -1 & 0,538 & 0,700 & 30,95 & 5 & 4,5 & 2,30 & 200 & 0,0664 & 10 \\
\hline 13 & 1 & 1 & -1 & -1 & 0,512 & 0,656 & 32,67 & 5 & 4,0 & 1,58 & 200 & 0,0331 & 14 \\
\hline 14 & -1 & 1 & -1 & -1 & 0,538 & 0,656 & 29,81 & 5 & 4,0 & 0,85 & 200 & 0,0663 & 15 \\
\hline 15 & 1 & -1 & -1 & -1 & 0,525 & 0,636 & 32,86 & 5 & 5,0 & 1,46 & 200 & 0,0662 & 15 \\
\hline 16 & -1 & -1 & -1 & -1 & 0,525 & 0,677 & 30,86 & 5 & 4,5 & 0,78 & 200 & 0,0662 & 14 \\
\hline 17 & 2 & 0 & 0 & 0 & 0,525 & 0,636 & 33,57 & 5 & 4,0 & 1,58 & 200 & 0,0663 & 10 \\
\hline 18 & -2 & 0 & 0 & 0 & 0,568 & 0,677 & 28,33 & 5 & 4,0 & 0,90 & 170 & 0,0995 & 9 \\
\hline 19 & 0 & 2 & 0 & 0 & 0,553 & 0,656 & 33,57 & 5 & 3,5 & 0,85 & 191 & 0,0332 & 10 \\
\hline 20 & 0 & -2 & 0 & 0 & 0,538 & 0,677 & 30,38 & 5 & 4,0 & 1,31 & 136 & 0,1326 & 9 \\
\hline 21 & 0 & 0 & 2 & 0 & 0,568 & 0,700 & 29,67 & 5 & 3,5 & 1,64 & 199 & 0,0996 & 11 \\
\hline 22 & 0 & 0 & -2 & 0 & 0,525 & 0,656 & 30,95 & 5 & 5,0 & 1,35 & 199 & 0,0995 & 23 \\
\hline 23 & 0 & 0 & 0 & 2 & 0,568 & 0,700 & 27,52 & 5 & 3,5 & 0,67 & 194 & 0,0660 & 10 \\
\hline 24 & 0 & 0 & 0 & -2 & 0,512 & 0,636 & 32,62 & 5 & 5,0 & 1,94 & 200 & 0,0659 & 12 \\
\hline 25 & 0 & 0 & 0 & 0 & 0,525 & 0,677 & 31,57 & 5 & 5,0 & 1,46 & 178 & 0,0662 & 12 \\
\hline 26 & 0 & 0 & 0 & 0 & 0,525 & 0,677 & 31,43 & 5 & 4,5 & 1,58 & 181 & 0,0663 & 13 \\
\hline 27 & 0 & 0 & 0 & 0 & 0,538 & 0,700 & 31,10 & 5 & 5,0 & 1,20 & 184 & 0,0995 & 13 \\
\hline 28 & 0 & 0 & 0 & 0 & 0,525 & 0,677 & 30,95 & 5 & 5,0 & 1,46 & 183 & 0,0668 & 13 \\
\hline 29 & 0 & 0 & 0 & 0 & 0,525 & 0,656 & 31,52 & 5 & 5,0 & 1,94 & 176 & 0,0664 & 13 \\
\hline 30 & 0 & 0 & 0 & 0 & 0,538 & 0,677 & 31,48 & 5 & 5,0 & 1,49 & 199 & 0,0662 & 13 \\
\hline 31 & 00 & 0 & 0 & 0 & 0,538 & 0,656 & 31,24 & 5 & 5,0 & 1,78 & 180 & 0,0990 & 13 \\
\hline
\end{tabular}

Notes: $\mathrm{y}_{1}$-bulk density, g/cm³; $\mathrm{y}_{2}$-tapped density, $\mathrm{g} / \mathrm{cm}^{3}$, $\mathrm{y}_{3}$-flowability, s/100g; $\mathrm{y}_{4}$-tablets appearance, scores, $\mathrm{y}_{5}$-tableting process, scores; $\mathrm{y}_{6}-$ uniformity of weight, \%, $\mathrm{y}_{7}$-the tablets hardness, $\mathrm{N} ; \mathrm{y}_{8}$-the friability test, \%, $\mathrm{y}_{9}$-the disintegration time, min. 


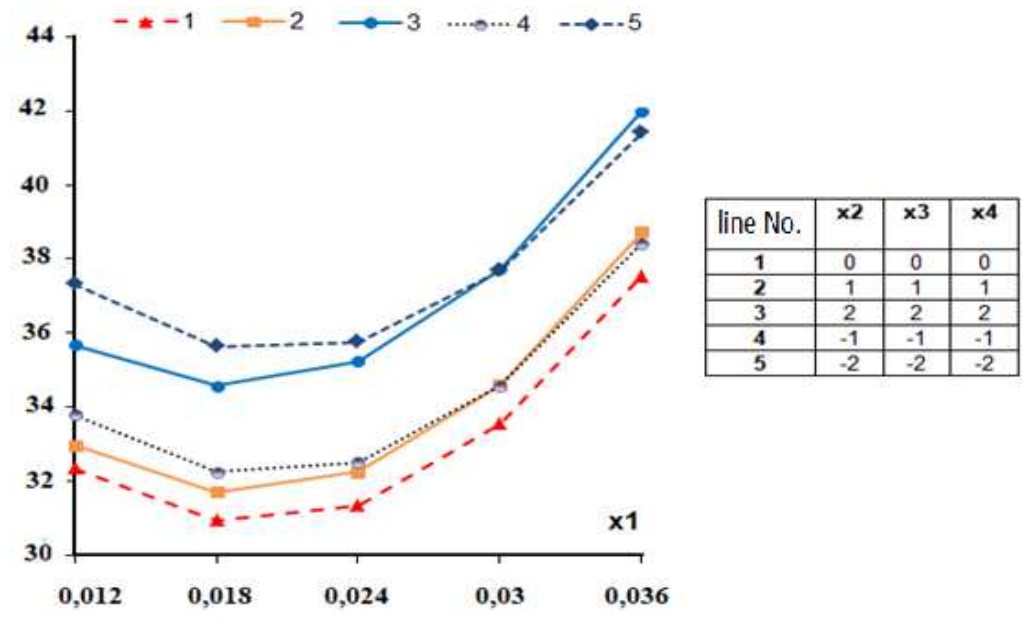

Fig. 1: The effect of Neusilin ${ }^{\circledR}$ US 2 amount $\left(x_{1}\right)$ on flowability of powder mixtures containing round-leaved wintergreen extract

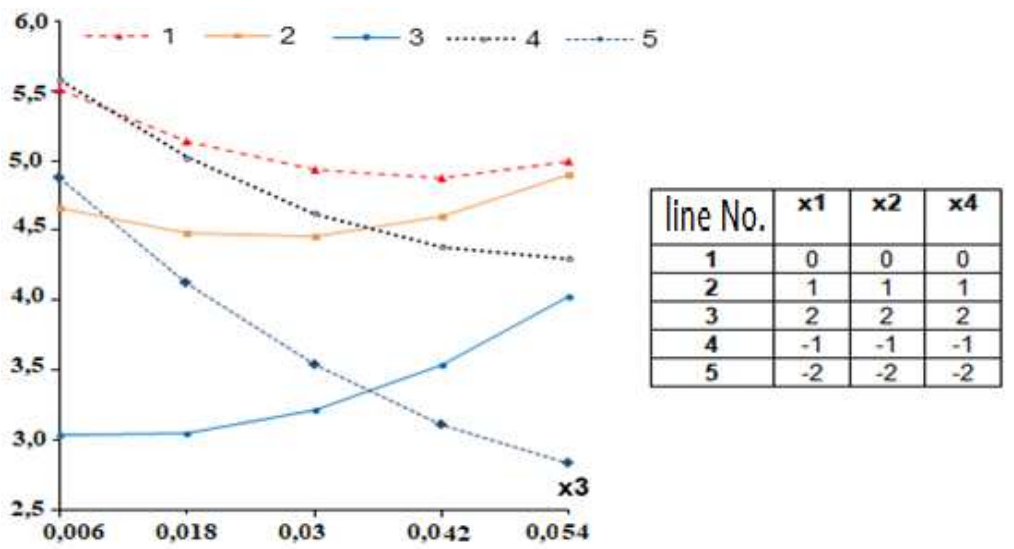

Fig. 2: The effect of croscarmellose sodium $\left(x_{3}\right)$ on appearance of tablets of round-leaved wintergreen extract

The best appearance values were provided by the amount of excipients, Neusilin ${ }^{\circledR}$ US 2 ( $\left.\mathrm{x}_{1}\right)$, PROSOLV ${ }^{\circledR}$ EASYtab SP ( $\left.\mathrm{x}_{2}\right)$, Tablettose ${ }^{\circledR} 80\left(\mathrm{x}_{4}\right)$ at the basic level (line 1). The change in the amounts of croscarmellose sodium $\left(\mathrm{x}_{3}\right)$ at the basic level affected the appearance as follows: the lower star point (5.5 points), the lower level (5.1 points), the basic level (4.93 points), the upper level $(4,88$ points) and the upper star point (4.99 points). It is experimentally established that the investigated excipients in the composition of round-leaved wintergreen extract within the studied intervals do not affect the compression process. All series of experiments on the process of pressing tablets of round-leaved wintergreen got 5 points.

The relationship between the factors studied and the uniformity of tablet weight is described by the following regression equation:

$\mathrm{y}_{6}=1,56+0,18 \mathrm{x}_{3}-0,15 \mathrm{x}_{4}-0,26 \mathrm{x}_{1} \mathrm{x}_{3}-0,26 \mathrm{x}_{3} \mathrm{x}_{4}$

The effect of the most significant factor, the amount of croscarmellose sodium $\left(\mathrm{x}_{3}\right)$ on the uniformity of the tablets dosage is shown in fig. 3

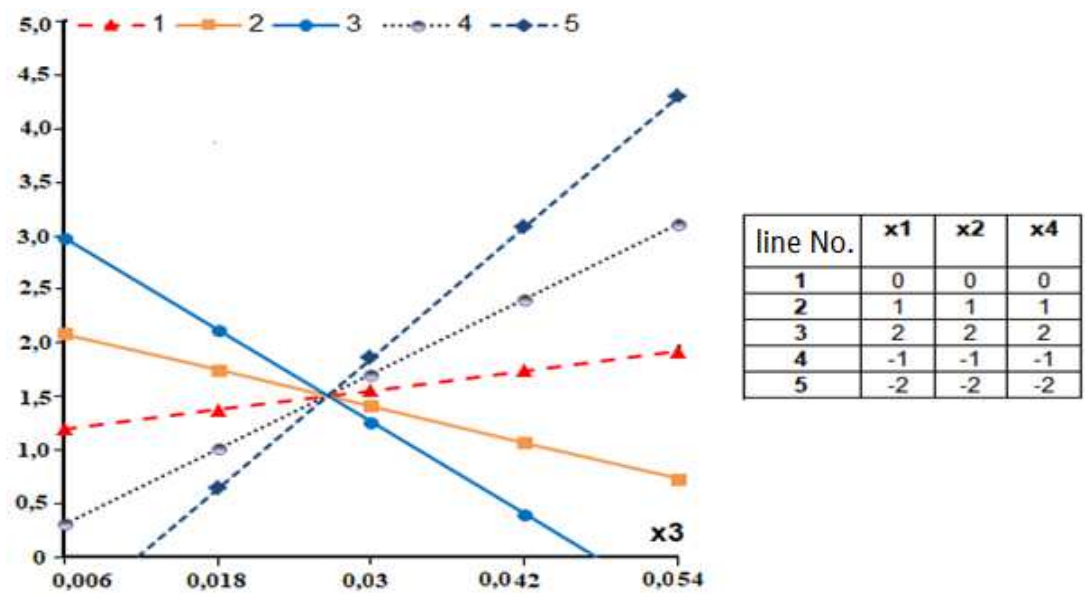

Fig. 3: The effect of croscarmellose sodium $\left(x_{3}\right)$ on uniformity of dosage units of tablets of round-leaved wintergreen extract 
Stable uniformity of dosage units in the range from $1.2 \%$ to $1.92 \%$ is provided by the amount of Neusilin ${ }^{\circledR}$ US $2\left(\mathrm{x}_{1}\right)$, PROSOLV ${ }^{\circledR}$ EASYtab SP $\left(\mathrm{x}_{2}\right)$, Tablettose ${ }^{\circledR} 80\left(\mathrm{x}_{4}\right)$ when tested at the basic level (line 1), with an increase in the amount of croscarmellose sodium $\left(\mathrm{x}_{3}\right)$ leads to a deterioration in uniformity of tablets of round-leaved wintergreen extract. Increasing the amount of Tablettose ${ }^{\circledR} 80$ in the tablets composition leads to improved uniformity.
The relationship between the factors studied and the tablets hardness of round-leaved wintergreen extract is described by the following regression equation:

$$
\mathrm{y}_{7}=183,16+3,13 \mathrm{x}_{1}-3,09 \mathrm{x}_{2}^{2}+5,78 \mathrm{x}_{3}^{2}+5,28 \mathrm{x}_{4}^{2}
$$

The effect of the amount of Neusilin ${ }^{\circledR}$ US 2 (factor $\mathrm{x}_{1}$ ) on the tablets hardness of round-leaved wintergreen extract is shown in fig. 4

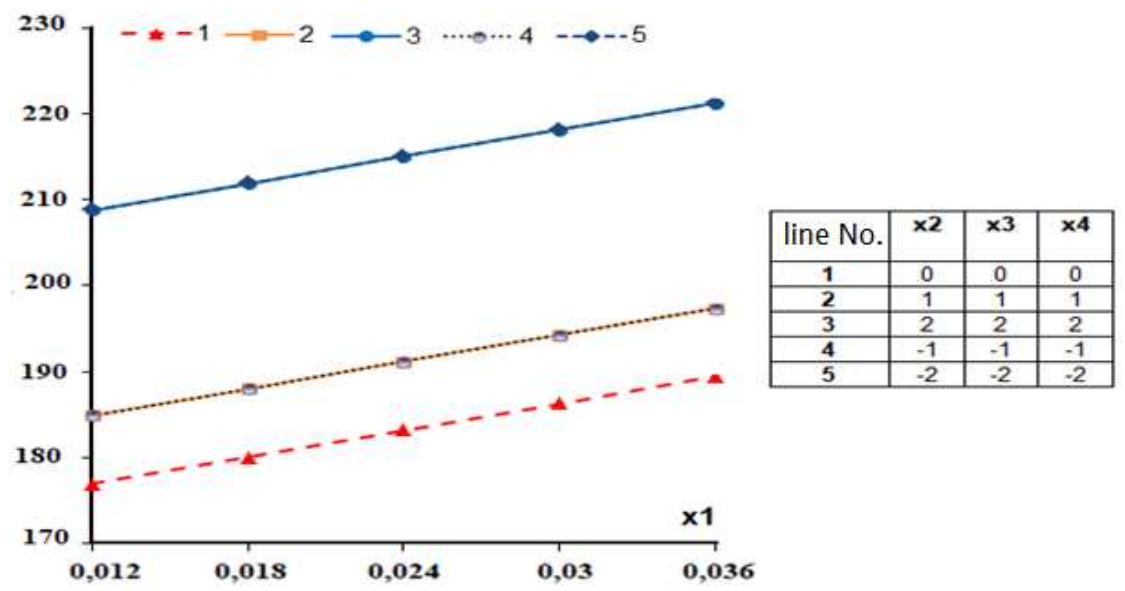

Fig. 4: The effect of the amount of Neusilin ${ }^{\circledR}$ US 2 (factor $\mathrm{x}_{1}$ ) on the tablets hardness of round-leaved wintergreen extract

At this stage of the study, they obtained tablets of round-leaved wintergreen extract with high resistance to crushing in all series of experiments.

The strength of the tablets increased with increasing amounts of Neusilin ${ }^{\circledR}$ US $2\left(\mathrm{x}_{1}\right)$ at different combinations of levels of the other three factors. The highest rates of tablet strength were observed when studying the amounts of PROSOLV ${ }^{\circledR}$ EASYtab SP ( $\left.\mathrm{x}_{2}\right)$, croscarmellose sodium $\left(\mathrm{x}_{3}\right)$, Tablettose ${ }^{\circledR} 80\left(\mathrm{x}_{4}\right)$ at the "upper star points" (lines 3 and 5), the lowest when stabilized at the basic level (line 1).

The relationship between the quantitative factors and friability of tablets of round-leaved wintergreen extract is described by the following regression equation:

$$
\mathrm{y}_{8}=0,076-0,0138 \mathrm{x}_{1}-0,01 \mathrm{x}_{1} \mathrm{x}_{3}+0,01 \mathrm{x}_{2} \mathrm{x}_{3}
$$

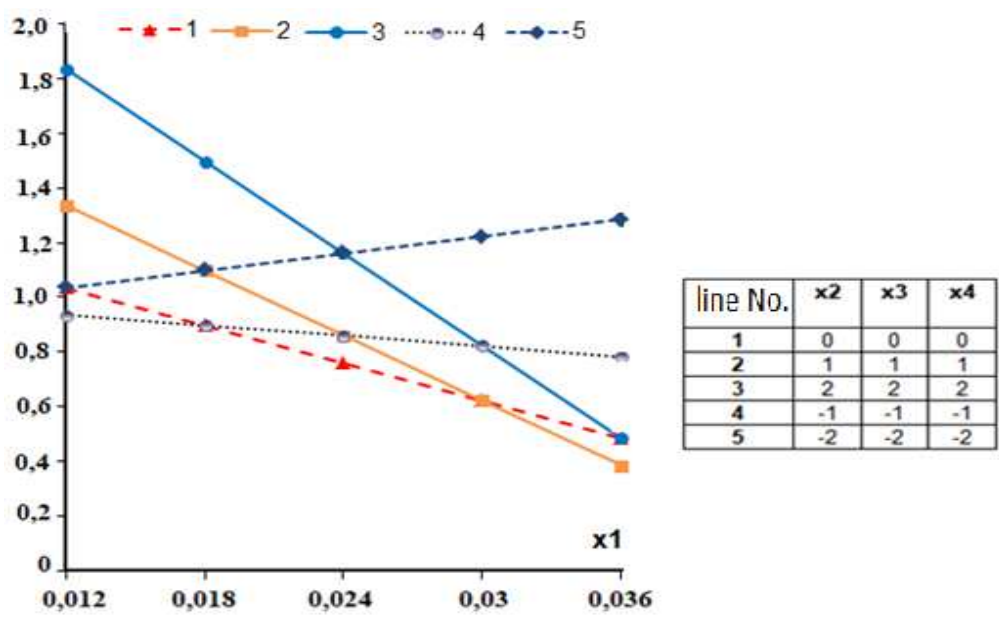

Fig. 5: The effect of the amount of Neusilin ${ }^{\circledR}$ US 2 (factor $x_{1}$ ) on the friability of tablets of round-leaved wintergreen extract

Fig. 5 shows that the highest friability of the tablets is observed when studying the factors $\mathrm{x}_{1}, \mathrm{x}_{2}, \mathrm{x}_{3}$ at the upper star points and the amounts of Neusilin ${ }^{\circledR}$ US $2\left(\mathrm{x}_{1}\right)$ at the lower star point, then the friability of tablets was $0.18 \%$; it should be noted that when increasing the amount of Neusilin ${ }^{\circledR}$ US 2 at this level, the friability of tablets improved significantly, and when studying the quantities of Neusilin ${ }^{\circledR}$ US $2\left(\mathrm{x}_{1}\right)$ at the upper star point it was $0.05 \%$.

The same value of the friability index was obtained when studying quantities of PROSOLV ${ }^{\circledR}$ EASYtab SP $\left(\mathrm{x}_{2}\right)$, croscarmellose sodium $\left(\mathrm{x}_{3}\right)$, Tablettose ${ }^{\circledR} 80\left(\mathrm{x}_{4}\right)$ at the basic level (line 1), and quantities of
Neusilin ${ }^{\circledR}$ US $2\left(\mathrm{x}_{1}\right)$ at the upper star point. It should be noted that reducing the amounts of $\mathrm{x}_{2}, \mathrm{x}_{3}, \mathrm{x}_{4}$ from the upper star point (line 3 ) to the basic level (line 1) significantly improves the friability rate.

The relationship between the factors studied and the disintegration of the studied tablets is described by the following regression equation:

$$
\begin{aligned}
\mathrm{y}_{9}= & 12,87+0,21 \mathrm{x}_{1}-2,38 \mathrm{x}_{3}-0,54 \mathrm{x}_{4}-0,31 \mathrm{x}_{1} \mathrm{x}_{2}-0,19 \mathrm{x}_{1} \mathrm{x}_{3}+0,19 \\
& \mathrm{x}_{2} \mathrm{x}_{4}+0,56 \mathrm{x}_{3} \mathrm{x}_{4}-0,91 \mathrm{x}_{1}{ }^{2}-0,91 \mathrm{x}_{2}{ }^{2}+0,96 \mathrm{x}_{3}{ }^{2}-0,54 \mathrm{x}_{4}{ }^{2}
\end{aligned}
$$

The effect of the most significant factor $\left(\mathrm{x}_{3}\right)$ on disintegration of the studied tablets is shown in fig. 6 


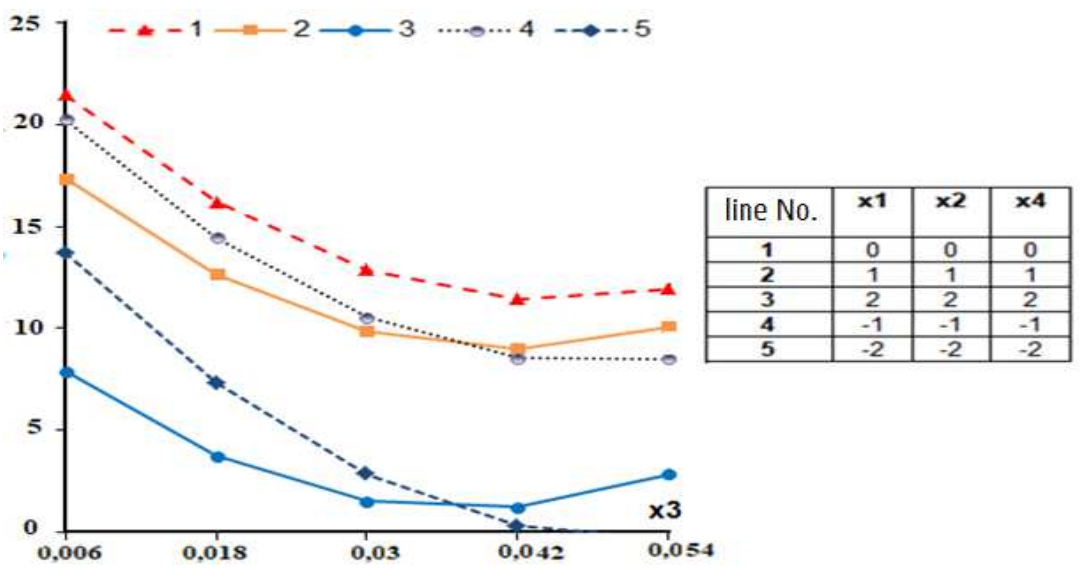

Fig. 6: The effect of croscarmellose sodium $\left(x_{3}\right)$ on the disintegration of tablets of round-leaved wintergreen extract

When studying the effect of the amounts of croscarmellose sodium on the disintegration of tablets of round-leaved wintergreen extract, it was found that the best disintegration values were obtained in the study of croscarmellose sodium at the upper level, and all other factors $\left(\mathrm{x}_{1}, \mathrm{x}_{2}, \mathrm{x}_{4}\right)$ at the upper star points. When studying the amounts of croscarmellose sodium at the lower star points, disintegration took the longest time in all cases.

Therefore, when analyzing the data obtained, it can be concluded that all the quality indicators of the tablets meet SPU requirements, when the amount of excipients was studied at the basic level, only the amount of croscarmellose sodium should be stabilized at the upper level to ensure better disintegration of tablets.

As a result of tests performed, based on the analysis of one-factor graphic drawings, the optimal composition of tablets of roundleaved wintergreen extract was determined; all ingredients should be taken in the following ratio: dry extract of round-leaved wintergreen $\left(0.300\right.$ g; 50\%), VIVAPUR ${ }^{\circledR} 112 \quad(0.114$ g; 19\%), PROSOLV ${ }^{\circledR}$ EASYtab SP $(0.072$ g; $12 \%)$, Croscarmellose sodium (0.042 g; 7\%), Tablettose ${ }^{\circledR} 80$ (0.042 g; 7\%), Neusilin ${ }^{\circledR}$ US 2 (0.024 g; $4 \%)$, Magnesium stearate $(0.006 \mathrm{~g} ; 1 \%$ ).

In the selection of the best excipients in the development of solid dosage forms, different approaches are used $[25,26]$. One of the best is to use mathematical experiment planning.

In the study of optimal ethanol concentration and the ratio of raw materials to extractant was used regression analysis. The alcoholic extract of Centaurium erythraea Rafn. with the highest content of hydroxycinnamic acid and phenolic compounds were obtained. By which the concentration of the extractant is $69 \%$ and the optimal ratio of raw material to extractant is 1 to 5 [4].

Therefore, the regression analysis was successfully used in the study of solid dosage forms as well as in the selection of optimal excipients.

\section{CONCLUSION}

The oral solid dosage form with a dry extract of round-leaved wintergreen was successfully prepared by the direct compression method. The optimal composition of tablets was determiend by the regression analysis. Shown successful use of a symmetric, rotatable composite plan of the second-order (uniform plan No. 17) in determining the effect of excipients on the quality of the tablets.

\section{AUTHORS CONTRIBUTIONS}

All the authors have contributed equally

\section{CONFLICTS OF INTERESTS}

The authors declare no conflict of interest

\section{REFERENCES}

1. Darzuli N, Vronska L, Groshovyi T, Beley N. Development of methods of standardization of medicinal plants-Pyrola rotundifolia leaf. Pharma Innov J 2017;6:17-21.

2. Darzuli N, Denys A, Hroshovyi T. Marketing research of the market of drugs and dietary supplements used for the treatment of inflammatory diseases of the urinary system. Pharm Rev 2017;4:50-6.

3. Slobodianiuk L, Budniak L, Marchyshyn S, Basaraba R. Determination of amino acids and sugars content in Antennaria dioica gaertn. Int J Appl Pharm 2019;11:39-43.

4. Stoiko L, Kurylo K. Development of optimal technology of alcohol extract Centaurium erythraea rafn herb. Arch Balk Med Union 2018;53:523-8.

5. Rożycki C, Synoradzki L. Teaching the experimental design. Lecture and exercises. Przemyst Chemiczny 2003;8-9:1342-4.

6. Patwari MAU, Nurul Amin AKM, Faris WF. Prediction of tangential cutting force in end milling of medium carbon steel by coupling design of experiment and response surface methodology. J Mech Eng 2009;40:95-103.

7. Patel V, Bisoniya TS. Experimental investigation of the effect of machining parameters on surface roughness in roller burnishing process. Int J Technol Res Engineer 2015;9:2201-4.

8. Bhagwat Durgacharan A, D'Souza John I. Development of solid self micro emulsifying drug delivery system with Neusilin US2 for enhanced dissolution rate of telmisartan. Int J Drug Dev Res 2012;4:398-407.

9. Dias RJ, Mali KK, Ghorpade VS, Havaldar VD, Mohite VR Formulation and evaluation of carbamazepine liquisolid compacts using novel carriers. Ind J Pharm Edu Res 2017;51:S69-S78.

10. Hentzschel CM, Sakmann A, Leopold CS. Suitability of various excipients as carrier and coating materials for liquisolid compacts. Drug Dev Ind Pharm 2011;37:1200-7.

11. Aljaberi A, Ardakani A, Khdair A, Abdel-Rahim SA, Meqdadi E, Ayyash $\mathrm{M}$, et al. Tableting functionality evaluation of prosolv easytab in comparison to physical mixtures of its individual components. J Drug Del Sci Tech 2013;23:499-504.

12. Prosolv EASYtab SP. Product overview. JRS Pharma. Available from: https://www.jrspharma.com/pharma_en/productsservices/excipients/hfe/prosolv-easytab-sp.php. [Last accessed on 01 Aug 2019].

13. Croscarmellose Sodium. Product overview. Available from: https://www.roquette.com/pharma-and-nutraceuticalscroscarmellose-sodium. [Last accessed on 01 Aug 2019]

14. Tablettose 80. Product overview. Available from: https://www.meggle-pharma.com/en/lactose/7tablettose80.html. [Last accessed on 01 Aug 2019]

15. Nelson D, Rebecca W, Wymbs K. Effect of magnesium stearate on tablet properties. Available from: https://pdfs.semanticscholar.org/ e009/ 14cd80edbba78a1b9d8643798efb715fa265.pdf. accessed on 01 Aug 2019] 
16. Jilika S, Monika T, Ajay KS, Amit RS. Study of microcrystalline cellulose as a substitute of magnesium stearate towards the functionality of lubricant in aspirin formulation. Int J Dev Res 2017;7:15879-84.

17. Marczynski Z, Zgoda MM, Bodek KH. Extract from Zingiber officinale rosc. in solid oral form of a drug. Herba Pol 2010;56:35-48.

18. Jaya S, Amala V. Formulation and in vitro evaluation of oral disintegrating tablets of amlodipine besylate. Int J Appl Pharm 2019;11:49-54.

19. Derzhavna Farmakopeya Ukrayini: v 3 t. Kharkiv: Derzhavne pidpriemstvo. Ukrayinskiy naukoviy farmakopeyniy tsentr yakosti likarskih zasobiv. State Pharmacopoeia Ukraine 2015;2:1121-5.

20. Barchuk OZ, Groshovyi TA, Zaliska OM, Shalata VJa. Study of the influence of excipients on pharmaco-technological properties of tablets based on the extract of bilberry leaves, extract of goat's rue herbs and taurine obtained by direct compression method. Pharm Rev 2018;1:47-56.

21. Maraie NK, Salman ZD, Yousif NZ. Design and characterization of or slippery buoyant tablets for ranitidine hydrochloride. Asian J Pharm Clin Res 2018;11:143-9.
22. Patel A, Patel D, Banker K. Effect evaluation of roller burnishing process on surface roughness of $6061 \mathrm{~T} 6 \mathrm{~A} \mathrm{l}$ alloy using response surface methodology. Int J Sci Res Dev 2014;8:142-5.

23. Suresh PVS, Venkateswara Rao P, Deshmukh SG. A genetic algorithmic approach for optimization of surface roughness prediction model. Int J Machine Tools Manuf 2002;42:67580.

24. Hroshovyi TA, Martsenyuk VP, Kucherenko LI, Vronska LV, Huryeyeva SM. Matematychne planuvannya eksperymentu v farmatsiyi [Mathematical planning of experiment in pharmacy]. Ternopil, Ukrainian: Ternopil State Medical University; 2008. p. 304-9.

25. Marczyński Z, Kowalczykiewicz K, Bodek KH. Selected excipients and surfactants in oral solid dosage form with extract of Phaseoli pericarpium (Phaseolus vulgaris L.). Herba Pol 2015;61:78-92.

26. Hiremath SP, Makanapur C. Formulation and evaluation of orodispersible tablets of a model anti-hypertensive drug. Int J Pharm Pharm 2017;9:34-8. 